\title{
GENERAL HILBERT-TYPE INEQUALITIES WITH NON-CONJUGATE EXPONENTS
}

\author{
AlEKSANDRA ČIŽMEŠIJA, MARIO KRNIĆ AND JOSIP PEČARIĆ
}

\begin{abstract}
In this paper we derive a series of new one-dimensional and multidimensional integral and discrete inequalities of the Hilbert and the Hardy-Hilbert type, with non-conjugate exponents. First, prove and discuss two equivalent general inequalities of such type, as well as their corresponding reverse inequalities. The obtained results are then applied to various settings considering homogeneous functions of a negative real degree. In particular, we prove generalizations and refinements of some recent results of Rassias et al, related to the Hilbert-type inequalities with conjugate exponents, and some new multidimensional inequalities of the Godunova type.
\end{abstract}

Mathematics subject classification (2000): 26D10, 26D15.

Key words and phrases: Inequalities, Hilbert's inequality, Hardy-Hilbert inequality, non-conjugate exponents, homogeneous kernel.

\section{REFERENCES}

[1] M. Abramowitz And I. A. Stegun (EDS.), Handbook of Mathematical Functions with Formulas, Graphs, and Mathematical Tables, $9^{\text {th }}$ printing, Dover, New York, 1972.

[2] F. F. BonsalL, Inequalities with non-conjugate parameters, Quart. J. Math. Oxford Ser. (2) 2 (1951), $135-150$.

[3] M. GAO AND L C. HSU, A survey of various refinements and generalizations of Hilbert's inequalities J. Math. Res. Exposition 25 (2) (2005), 227-243.

[4] E. K. Godunova, Generalization of a two-parameter Hilbert inequality, (Russian) Izv. Vysš. Učebn. Zaved. Matematika 196756 (1) (1967), 35-39.

[5] G. H. HARDY, J. E. LitTLEWOOD, AND G. PólYA, Inequalities, $2^{\text {nd }}$ edition, Cambridge University Press, Cambridge, 1967.

[6] I. BRNETIĆ AND J. PeČARIĆ, Generalization of inequalities of Hardy-Hilbert type, Math. Inequal. Appl. 7 (2) (2004), 217-225.

[7] M. KRnIĆ AND J. PeČARIĆ, General Hilbert's and Hardy's inequalities, Math. Inequal. Appl. 8 (1) (2005), 29-51.

[8] J. KuANG AND T. M. Rassias, Hilbert integral operator inequalities, Math. Inequal. Appl. 3 (4) (2000), 497-510.

[9] V. LEVIN, On the two-parameter extension and analogue of Hilbert's inequality, J. London Math. Soc. 11 (1936), 119-124.

[10] LJ. MARANGUNIĆ AND J. PeČARIĆ, On some new majorized results on Hilbert integral inequality, Int. J. Pure Appl. Math. 12 (2) (2004), 177-188.

[11] LJ. MARANGUNIĆ AND J. PEČARIĆ, Some remarks on Hilbert's integral inequality, Rev. Anal. Numér. Théor. Approx. 34 (1) (2005), 71-78.

[12] D. S. MitRINOVIĆ, J. E. PEČARIĆ, AND A. M. FInK, Classical and new inequalities in analysis, Kluwer Academic Publishers, Dordrecht/Boston/London, 1993.

[13] B. YANG AND T. M. RASSIAS, On the way of weight coefficient and research for the Hilbert-type inequalities, Math. Inequal. Appl. 6 (4) (2003), 625-658. 